\title{
Commentary on Morality, Decision Making, and Collateral Casualties
}

\author{
Morton Deutsch \\ Teachers College \\ Columbia University
}

Colonel Roblyer has presented a superb article that clearly poses the moral dilemmas facing military personnel when they have to choose whether or not to attack an appropriate military target when such an attack may cause harm to noncombatants. He discusses with great insight the biasing factors that may lead military decision makers to overestimate the benefits of the attack and to underestimate its harmfulness to noncombatants. He also makes excellent recommendations for increasing the sensitivity to the moral issues involved in military attacks, for reducing the biases that affect decision making and for providing more accurate information about the effects of attacks upon noncombatants. He manages extraordinarily well to convey the moral issues involved in military decision making despite the military usage of the depersonalizing term collateral casualties as a substitute for civilian casualties.

Colonel Roblyer's discussion focuses on helping "military decision-makers and their staffs to reason better with moral matters firmly in mind" (p. XX). His context is military decisions made by commanding officers during combat once a war has begun. Although this is an important context, I suggest that the context of his discussions should be broadened to include the Commander-in-Chief, the President. Is it not crucially important that the President and his or her staff "reason better with moral matters firmly in mind" (p. XX) before they choose whether or not to initiate a war? Should not such decisions be guided by "the moral roots of the legal standards of international law, especially the principle of humanity?" (p. $\mathrm{XX}$ ). Should not the threat of the potential biases and partiality in the judgments and decisions of the President and his staff, which might favor military necessity, be taken seriously and guarded against?

Requests for reprints should be sent to Morton Deutsch. The International Center for Cooperation and Connflict Resolution, Box 53. Teachers College. Columbia University, 525 West 120 th Street, New York, NY 10025. E-mail: Deutsch@exchange.tc.columbia.edu 
are three basic ways of reducing the typical misjudgments and misperceptions that occur during conflict (see Deutsch 1962, 1965, for a description of some of their common sources). They are not mutually exclusive, and if possible all should be used:

One method entails making explicit the assumptions and evidence that underlie one's perceptions and judgments. Then one would examine how likely these were to have been influenced by any of the common sources of misperception and misjudgments and how reliable and valid they would be considered by an objective outsider in court of law, for example.

A second method entails bringing in outsiders to see whether their judgments and perceptions of the situation are in agreement or disagreement with one's own. They may have different vantage points, different sources of information, and more objectivity, which would enable them to recognize errors of judgment and misperceptions developing from enmeshment in the conflict. The oursiders should have the independence to ensure that they are free to form their own views and the stature to be able to communicate them so that they will be heard.

When the nature of the conflict is such that the employment of objective outsiders is not feasible, the use of internal devil's advocates has been recommended (George, 1972; Janis, 1972) as a way of challenging the assumptions and evidence underlying one's perceptions and judgments. Here, too, it is important that the devil's advocates be sufficiently independent and prestigious to present hard challenges to conventional views in a way that cannot be ignored.

Finally, there are agreements that can be made with one's adversary to reduce the chances of malignant misjudgment and misperceptions during conflict. Such agreements could promote continuing informal contacts among international affairs and military specialists on both sides. They could provide for regular feedback of each side's interpretations of the other's communications. They could enable each side to present its viewpoints on television and in the mass media of the other side on a regular basis. They could provide for role-reversal enactments, where each side is required to state the position of the other side to the other side's complete satisfaction before either side advocates its own position (Rapoport, 1960).

None of the foregoing procedures would be certain to eliminate all misperceptions and misjudgments during conflict. Yet, in combination, they might substantially reduce them and, in consequence, decrease the risks that conflict would escalate because of poor communication and misunderstandings. (Deutsch, 1985, pp. 271-272)

I now turn to the very difficult issue of how can one morally confront an immoral adversary who, for example, uses noncombatants or holy sites as shields or hostages to protect its military activity? An adversary who does this is violating international rules of war and, accordingly to those rules, one has the right to respond in such a way that one's adversary does not benefit from such actions. One is faced with the dilemma that a "successful" military attack on one's adversary may cause much harm not only to the hostages but also to one's support and reputation in the 
For example, the Bush Administration made the decision to initiate a war against Iraq. There is much evidence to suggest that the principles underlying Colonel Roblyer's article did not play an influential role in making this vital decision. I come to this conclusion based on the public record that indicates that little attempt was made to prevent or eliminate the biases favoring the decision to attack Iraq and also that the international normative standards regarding initiating a war were disregarded by the Bush Administration.

Despite intense urgings from the Bush Administration, the United Nations (UN) Security Council did not support its decision to go to war. The UN Secretary General has called it an "illegal war." Public opinion polls in many nations indicated that there was very widespread and strong opposition by most of the world's citizens to the war. The Egyptian Foreign Minister (September 20, 2004, on Charlie Rose's PBS program) stated that the Arab nations urged the Bush Administration not to go to war against Iraq. Before the UN inspectors completed their investigation and report of whether or not Iraq possessed weapons of mass destruction, Iraq was attacked strongly by the military force of the United States. In other words, the Bush Administration not only disregarded international normative standards for initiating a war, it also did not heed the views of the Arab nations that would be most adversely affected if Iraq had weapons of mass destruction, it did not take into account humankind's opposition, and it aborted an objective attempt to determine whether the avowed reason to initiate war against Iraq was valid - that Iraq had weapons of mass destruction.

Suppose the Bush Administration felt that it had invincible evidence that Iraq posed a "Supreme Emergency" (Schrepel, this issue) for the United States. If so, they could claim that it was their moral obligation to eliminate the "Supreme Emergency" by initiating a war against Iraq. Such a claim would have moral validity only if they had exerted maximum effort to eliminate biases in their information collection and decision making and had thoroughly considered alternatives to military force as a way of eliminating the threats posed by Iraq. It is obvious now that the claim that Iraq posed an imminent threat was false and thus invalidated this moral basis for a war against Iraq. There have been other subsequent justifications such as if Saddam Hussein's regime controlled Iraq, a threat would develop sooner or later, and if Saddam Hussein's regime were eliminated, democracy would develop in Iraq and that, in turn, would lead to the democratization of Arab countries and to a more peaceful Middle East. I do not think that either of these justifications, singly or combined, would pass the test of objective decision making that morally considers intemational legality of the war as well as the likely human costs and losses resulting from a war compared to its likely benefits.

What can be done to reduce the misperceptions and misjudgments that typically occur during the course of conflict whether the issue is to initiate a war or not, or to attack a given target during a war? In addition to the excellent suggestions for training made in the articles by Roblyer and Schrepel, I would suggest that there 
local as well as in larger communities. If there is much local opposition to the adversary's use of such hostages, it would seem desirable to provide the local groups with the assistance necessary to take responsibility for making the decisions and taking the actions in such a situation. On the other hand, if the local community is supportive of one's adversary and its use of local hostages as a shield, then clearly it is inappropriate to view one's forces as "liberators" of the community. However, if the broader community, of which the local community is a component, is opposed to the use of hostages, then the responsibility for decision making and action resides in that broader community. They may well decide to take nonviolent action such as massive demonstrations or appeals by religious leaders rather than military action against the hostage takers. As Schrepel has well pointed out, military reprisals against terrorists or hostage takers may produce the result that terrorists seek: excessive civilian deaths that "breed resentment against security forces and the government, generating a new cohort of revolutionaries."

Let me conclude by stating that $I$ admire the important and thoughtful articles by Roblyer and Schrepel and hope that they will be taken-to-heart not only by military personnel but also by civilian leaders such as the President, the members of the National Security Council, and the members of Congress.

\section{BIOGRAPHICAL NOTE}

Morton Deutsch served as a lead navigator in the United States 8 th Air force in World War II. He flew in 30 combat missions over Occupied Europe and Germany in a B-24, a heavy bomber. His personal experiences of the horrors of war have led him to focus much of his work in psychology on preventing destructive conflicts and fostering cooperative relations.

\section{REFERENCES}

Deutsch, M. (1962). A psychological basis for peace. In Q. Wright, W. M.. Evan, \& M. Deutsch (Eds.), Preventing World War III: Some proposals (pp. 1-19). New York: Simon \& Schuster.

Deutsch, M. (1965). A psychological approach to international conflict. In G. Sperrazzo (Ed.), Psychology and international relations (pp. 369-392). Washington, DC: Georgetown University Press.

Deutsch. M. (1985). Distributive justice: A social-prychologicat perspective. New Haven, CT: Yale University Press.

George, A. (1972). The case for multiple advocacy in making foreign policy. American Political Science, 66 .

Janis, 1. (1972). Vicimis of groupthink. Boston: Houghton Mifflin.

Rapoport, A. (1960). Fights, games, and debates. Ann Arbor: University of Michigan Press. 